\title{
PENGARUH KUALITAS LAYANAN SMS BANKING TERHADAP LOYALITAS NASABAH PT BANK RAKYAT INDONESIA KANTOR CABANG MADIUN
}

\author{
Agus Yan Praptasany, Elva Nuraina dan Purweni Widhianningrum \\ Program Studi Pendidikan Akuntansi - FPIPS \\ IKIP PGRI MADIUN
}

\begin{abstract}
ABSTRAK
Loyalitas nasabah adalah puncak pencapaian pelaku bisnis perbankan. Nasabah yang puas dan setia tidak akan ragu untuk menjadi penyebar kabar baik yang selalu menyebarkan kebaikan mengenai produk perbankan yang di gunakannya. Penelitian ini bertujuan untuk menguji pengaruh kualitas layanan yang terdiri dari bukti fisik, kehandalan, daya tanggap, jaminan dan empati secara parsial dan simultan terhadap loyalitas nasabah PT Bank Rakyat Indonesia kantor cabang Madiun. Populasi penelitian ini adalah nasabah yang menggunakan SMS Banking di PT Bank Rakyat Indonesia kantor cabang Madiun. Sampel perbankan dalam penelitian ini adalah nasabah selama periode awal tahun 2013 sampai dengan bulan Maret 2014. Pengambilan sampel dilaksanakan dengan teknik Indidental Sampling sehingga didapat sampel sejumlah 377 responden. Pengumpulan data pada penelitian ini didapat dengan wawancara dan kuisioner. Metode analisis yang digunakan dalam penelitian ini adalah Analisis Regresi Linear Berganda. Dari hasil uji parsial yang telah dilakukan didapatkan hasil bahwa bukti fisik, daya tanggap, kehandalan, jaminan dan empati berpengaruh secara parsial terhadap loyalitas nasabah PT Bank Rakyat Indonesia Cabang Madiun. Hal ini dikarenakan kelengkapan fisik ruang kantor, kecepatan, ketepatan, keamanan, kemudahan bertransaksi dengan SMS Banking mempengaruhi loyalitas nasabah Bank Rakyat Indonesia Cabang Madiun. Dari hasil uji simultan diperoleh hasil bahwa kualitas layanan yang terdiri dari bukti fisik, daya tanggap, kehandalan, jaminan dan empati secara simultan berpengaruh terhadap loyalitas nasabah PT Bank Rakyat Indonesia kantor cabang Madiun. Hal ini menunjukkan apabila Dimensi kualitas layanan dilaksanakan secara bersama - sama akan membuat nasabah semakin Loyal.
\end{abstract}

Kata Kunci : Kuailtas Layanan, SMS Banking, earning, Loyalitas Nasabah.

\section{PENDAHULUAN}

Salah satu perkembangan teknologi sekarang adalah di sektor teknologi informasi. Tidak bisa dibantah lagi, kemajuan teknologi informasi ini ikut menambah tantangan yang dihadapi oleh perbankan. Perkembangan teknologi informasi (TI) menyebabkan makin pesatnya perkembangan jenis dan kompleksitas produk dan jasa bank. Dukungan TI (teknologi informasi) bagi industri perbankan merupakan sebuah keharusan. Tak terbayangkan jika saat ini industri perbankan bergerak tanpa dukungan TI yang memadai.

Bank sebagai lembaga keuangan yang menghasilkan jasa keuangan juga membutuhkan strategi pemasaran untuk memasarkan produknya. Dampak dari perubahan teknologi juga berdampak positif terhadap perkembangan dunia perbankan produk yang ditawarkan kepada nasabahnya menjadi lebih cepat dan efisien. Sebagai contoh untuk melakukan pengiriman uang (transfer) dapat dilakukan pada saaat itu juga dengan sistem on line komputer. Padahal sebelumnya untuk mengirim uang dari satu bank ke lokasi lainnya memerlukan waktu beberapa hari (Kasmir, $2010: 2$ ) 
Bank merupakan salah satu perusahaan jasa yang bergerak dalam bidang finansial. Seperti diketahui prosedur transaksi pada setiap bank di Indonesia tidak jauh berbeda dimana biasanya dimulai dengan penulisan data terlebih dahulu, mengantri, lalu dilanjutkan dengan proses transaksi dimana terjadi tatap muka langsung antara nasabah dan teller. Proses ini cukup menyita waktu dan tidak jarang menyebabkan ketidak nyamanan ketika nasabah harus mengantri dalam waktu yang cukup lama. Namun dengan penggunaan teknologi canggih di sektor perbankan dipastikan akan mengubah pola transaksi. Kegiatan bank yang tadinya lebih banyak disibukkan dengan transaksi yang berkaitan dengan uang tunai, penarikan dan penyetoran uang, akan menjadi lebih praktis dan cepat tanpa harus nasabah direpotkan untuk antri dan menulis setoran. Produk perbankan yang mengunakan teknologi informasi atau yang biasa disebut dengan mobile banking atau disingkat dengan mBanking. Dengan adanya kemajuan dibidang teknologi informasi ini nasabah dapat melakukan transaksi darimana saja dan kapan saja.

Pada saat yang bersamaan, teknologi ini pula yang akan menjadi senjata bagi bank yang bersangkutan untuk bersaing dengan bank - bank lain, terutama dalam usahanya untuk menciptakan suatu produk pelayanan yang lebih murah, lebih baik, dan lebih cepat. Berikut, dijelaskan beberapa teknologi layanan perbankan antara lain adalah Mobil Banking (Wiji Nurastuti, 2011:110). Salah satu produk mobile banking tersebut adalah sms banking. SMS Banking merupakan salah satu alternatif elektronik channel yang menggunakan mobile phone banking sebagai device-nya dan messaging system atau short message system (SMS) sebagai media transaksinya. Layanan ini diharapkan mampu memberikan kemudahan kepada nasabah dalam bertransaksi any time, any where, any device. (Buku Pedoman Operasional - SMS Banking BRI, 2008 : 2).

Bagi nasabah yang memilki tingkat kesibukan yang tinggi sehingga tidak sempat pergi ke bank kerena terhalang oleh rutinitas kesibukan, maka layanan SMS Banking bisa menjadi solusi bagi nasabah Bank Rakyat Indonesia tersebut. Hal ini dapat menimbulkan minat nasabah untuk menggunakan SMS Banking Bank Rakyat Indonesia secara inten sehingga dapat meningkatkan loyalitas terhadap Bank Rakyat Indonesia.

\section{PEMENGEMBANGAN HIPOTESIS}

Penelitian yang dilakukan oleh Juhari (2012) tentang Analisis Pengaruh Kualitas Layanan Terhadap Loyalitas Pelanggan Pada Hotel Centrum Pangakalpinang bahwa kualitas pelayanan secara parsial, variabel kualitas layanan yang terdiri dari bukti langsung berpengaruh secara signifikan dan positif terhadap loayalitas pelanggan. Ketut Gunawan dan Sundring Pantja Djati (2011) menyebutkan bahwa variabel kualitas layanan yang terdiri dari dimensi variabel bukti langsung berpengaruh secara signifikan dan positif terhadap loayalitas pelanggan. Hais Dama (2010) menemukan bahwa variabel Bukti Langsung berpengaruh signifikan secara parsial terhadap loyalitas nasabah. Berdasarkan uraian diatas maka hipotesis yang dibangun sebagai berikut :

$\mathrm{H}_{1}$ : $\quad$ Bukti Langsung berpengaruh signifikan terhadap tingkat loyalitas nasabah.

Penelitian yang dilakukan oleh Hais Dama (2010) tentang pengaruh kualitas pelayanan terhadap loyalitas nasabah pada bank mandiri cabang gorontalo bahwa keandalan berpengaruh parsial secara positif terhadap loyalitas nasabah. Penelitian yang dilakukan oleh Ketut Gunawan dan Sundring Pantja Djati (2011) tentang Kualitas Layanan dan Loyalitas Pasien (Studi pada Rumah Sakit Umum Swasta di Kota Singaraja-Bali) bahwa variabel kualitas layanan yang terdiri dari dimensi variabel Keandalan berpengaruh secara signifikan dan positif terhadap loyalitas pelanggan. Penelitian yang dilakukan oleh Ernani Hidayati (2010) tentang Analisis Kualitas Pelayanan dan Pengaruhnya Terhadap 
Loyalitas Pelanggan bahwa variabel kualitas layanan yang terdiri dari dimensi variabel Keandalan berpengaruh secara signifikan terhadap loyalitas pelanggan.

Berdasarkan uraian diatas maka hipotesis yang dibangun sebagai berikut :

$\mathrm{H}_{2}$ : Keandalan berpengaruh signifikan terhadap tingkat loyalitas nasabah.

Penelitian yang dilakukan oleh Ketut Gunawan dan Sundring Pantja Djati (2011) tentang Kualitas Layanan dan Loyalitas Pasien (Studi pada Rumah Sakit Umum Swasta di Kota Singaraja-Bali) bahwa melalui ke Daya Tanggap ingin mendapatkan respon pasien sejauh mana pihak rumah sakit umum swasta di kota Singaraja memberikan respon yang berkaitan dengan ke Daya Tanggap petugas atas keluhan dan masalah yang dihadapi, keramah tamahan petugas, kecepatan petugas, kelengkapan fasilitas, makanan dan minuman yang berkualitas. Berdasarkan hasil uji parsial menunjukkan bahwa KeDaya Tanggap mempunyai pengaruh positif dan signifikan terhadap tingkat loyalitas pasien Rumah sakit Umum di kota Singaraja-Bali. Penelitian yang dilakukan oleh Ernani Hidayati (2010) tentang Analisis Kualitas Pelayanan dan Pengaruhnya Terhadap Loyalitas Pelanggan bahwa variabel kualitas layanan yang terdiri dari dimensi variabel Daya Tanggap berpengaruh secara signifikan terhadap loyalitas pelanggan. Penelitian yang dilakukan oleh Hais Dama (2010) tentang Pengaruh Kualitas Pelayanan Terhadap Loyalitas Nasabah Pada Bank Mandiri Cabang Gorontalo bahwa variabel kualitas layanan yang terdiri dari dimensi variabel Daya Tanggap berpengaruh secara signifikan dan positif terhadap loyalitas pelanggan.

Berdasarkan uraian diatas maka hipotesis yang dibangun sebagai berikut :

$\mathrm{H}_{3}$ : Daya Tanggap berpengaruh signifikan terhadap tingkat loyalitas nasabah.

Penelitian yang dilakukan oleh Siti Fatona (2010) tentang Kualitas Jasa yang mempengaruhi loyalitas dan relevansinya terhadap kepuasan bahwa variabel Jaminan berpengaruh signifikan secara parsial terhadap loyalitas nasabah kredit. Penelitian yang dilakukan oleh Ernani Hidayati (2010) tentang Analisis Kualitas Pelayanan dan Pengaruhnya Terhadap Loyalitas Pelanggan bahwa variabel kualitas layanan yang terdiri dari dimensi variabel Jaminan berpengaruh secara signifikan terhadap loyalitas pelanggan. Penelitian yang dilakukan oleh Hais Dama (2010) tentang Pengaruh Kualitas Pelayanan Terhadap Loyalitas Nasabah Pada Bank Mandiri Cabang Gorontalo bahwa variabel kualitas layanan yang terdiri dari dimensi variabel Jaminan berpengaruh secara positif terhadap loyalitas pelanggan.

Berdasarkan uraian diatas maka hipotesis yang dibangun sebagai berikut :

$\mathrm{H}_{4}$ : Jaminan berpengaruh signifikan terhadap tingkat loyalitas nasabah.

Penelitian yang dilakukan oleh Juhari (2012) tentang Analisis Pengaruh Kualitas Layanan Terhadap Loyalitas Pelanggan Pada Hotel Centrum Pangakalpinang bahwa kualitas pelayanan secara parsial, variabel kualitas layanan yang terdiri dari dimensi variabel Empati berpengaruh secara signifikan dan positif terhadap loayalitas pelanggan. Penelitian yang dilakukan oleh Ketut Gunawan dan Sundring Pantja Djati (2011) tentang Kualitas Layanan dan Loyalitas Pasien (Studi pada Rumah Sakit Umum Swasta di Kota Singaraja-Bali) bahwa variabel kualitas layanan yang terdiri dari dimensi variabel Empati berpengaruh secara signifikan dan positif terhadap loayalitas pelanggan. Penelitian yang dilakukan oleh Winarti Setyorini (2011) tentang Pengaruh Kualitas Pelayanan Terhadap Loyalitas Pelanggan Pada Hotel Mahkota di Pangkalan BUN bahwa variabel kualitas layanan yang terdiri dari dimensi variabel Empati berpengaruh secara signifikan terhadap loyalitas pelanggannya.

Berdasarkan uraian diatas maka hipotesis yang dibangun sebagai berikut :

$\mathrm{H}_{5}$ : Empati berpengaruh signifikan terhadap tingkat loyalitas nasabah. 


\section{METODA PENELITIAN}

Populasi, Data dan Sampel

Populasi dalam penelitian ini adalah seluruh nasabah baik nasabah Britama maupun Simpedes yang terdaftar sebagai pengguna layanan Short Message System Banking Bank Rakyat Indonesia di area wilayah kantor cabang Bank Rakyat Indonesia Madiun.

Peneliti menentukan jumlah sampel yang diambil dengan menggunakan rumus Yamane (Jonathan Sarwono dan Ely Suhayati, 2010 : 57). Teknik pengambilan sampel pada penelitian ini menggunakan metode insidental Sampling. Pengambilan sampel dilakukan dengan menggunakan teknik sampling insidental. Untuk pengambilan teknik Insidental Sampling dilaksanakan di kantor Bank Rakyat Indonesia cabang Madiun.

Analisis regresi linear berganda digunakan untuk meramalkan variabel dependen jika variabel independen dinaikan atau diturunkan.

Untuk melakukan peramalan maka dibuatlah persamaan sebagai berikut :

$$
\mathrm{Y}=\mathrm{b0}+\mathrm{b} 1 \mathrm{X} 1+\mathrm{b} 2 \mathrm{X} 2+\mathrm{b3X3}+\mathrm{b4X4}+\mathrm{b5X5}
$$

Keterangan:

$\begin{array}{ll}\text { Y } & =\text { Loyalitas nasabah } \\ \text { X1 } & =\text { Bukti Langsung, } \\ \text { X2 } & =\text { Kehandalan } \\ \text { X3 } & =\text { Daya Tanggap } \\ \text { X4 } & =\text { Jaminan } \\ \text { X5 } & =\text { Empati, } \\ \text { Bo } & =\text { konstanta, } \\ \text { b1-b5 } & =\text { Koefisien regresi. }\end{array}$

ANALISIS DATA

Hasil uji regresi dalam penelitian ini tersaji sebagai berikut.

Tabel 1

Hasil Uji regresi

\begin{tabular}{|c|c|c|c|c|c|}
\hline \multirow[b]{2}{*}{ Model } & \multicolumn{2}{|c|}{$\begin{array}{c}\text { Unstandardized } \\
\text { Coefficients }\end{array}$} & \multirow{2}{*}{$\begin{array}{c}\text { Standardized } \\
\text { Coefficients } \\
\text { Beta }\end{array}$} & \multirow[t]{2}{*}{$\mathrm{t}$} & \multirow[t]{2}{*}{ Sig } \\
\hline & $B$ & $\begin{array}{c}\text { Std. } \\
\text { Error }\end{array}$ & & & \\
\hline$($ Constant) & 3,763 & 0,756 & & 8,058 & $\overline{, 000}$ \\
\hline Bukti fisik & 0,355 & 0,044 & 0,388 & 2,254 & 025 \\
\hline Keandalan & 0,068 & 0,030 & 0,096 & 4,212 &, 000 \\
\hline Daya tanggap & 0,140 & 0,033 & 0,185 & 3,635 &, 000 \\
\hline Jaminan & 0,143 & 0,039 & 0,152 & 3,536 &, 000 \\
\hline Empati & 0,129 & 0,036 & 0,145 & 8,058 & ,000 \\
\hline
\end{tabular}

1). Koefisien determinasi

Berdasarkan analisis koefisien korelasi berganda (R) sebesar 0,542 yang berarti menunjukkan adanya hubungan yang sangat kuat antara variabel bukti fisik, keandalan, daya tanggap, jaminan dan empati terhadap loyalitas nasabah. Sedangkan analisis koefisien determinasi $\left(\mathrm{R}^{2}\right)$ adalah 0,536 artinya perubahan loyalitas nasabah (Y) mampu diterangkan oleh perubahan variabel bukti fisik, keandalan, daya tanggap, jaminan dan empati secara bersama-sama sebesar 53,6\%. Sementara sisanya yaitu sebesar $46,4 \%$ dipengaruhi oleh variabel lain di luar variabel yang diteliti. 
2) Nilai F Regresi

Berdasarkan uji $\mathrm{F}$ menunjukkan bahwa $\mathrm{F}_{\text {hitung }}=87,811$ dan $\mathrm{F}_{\text {tabel }}=2,24$; maka $\mathrm{F}_{\text {hitung }}>\mathrm{F}$ tabel dengan tingkat kesalahan $0,000(0,000<0,05)$ maka hipotesis penelitian ini menolak Ho dan menerima Ha diterima artinya bahwa secara keseluruhan variabel bukti fisik, keandalan, daya tanggap, jaminan dan empati secara bersama-sama berpengaruh terhadap loyalitas nasabah.

3) Uji t (Nilai t Regresi)

Berdasarkan uji $\mathrm{t}$ untuk bukti fisik memiliki $t_{\text {hitung }}$ sebesar 8,058 dan $\mathrm{t}_{\text {tabel }}$ sebesar 1,966 (thitung $>t_{\text {tabel }}$ ). Kemudian dari tingkat signifikan $t$ sebesar 0,000 lebih kecil dari $0,05(0,000<0,05)$ maka hipotesis penelitian ini menolak Ho dan menerima Ha. Hipotesis yang menyatakan menerima Ha menunjukkan bahwa variabel bukti fisik secara partial memiliki pengaruh yang signifikan terhadap loyalitas nasabah.

Berdasarkan uji $t$ untuk keandalahan memiliki $t_{\text {hitung }}$ sebesar 2,254 dan $t_{\text {tabel }}$ sebesar 1,966 ( $\left.\mathrm{t}_{\text {hitung }}>\mathrm{t}_{\text {tabel }}\right)$. Kemudian dari tingkat signifikan $\mathrm{t}$ sebesar 0,008 lebih kecil dari $0,05(0,025<0,05)$ maka hipotesis penelitian ini menolak Ho dan menerima Ha. Hipotesis yang menyatakan menerima Ha menunjukkan bahwa variabel keandalan secara partial memiliki pengaruh yang signifikan terhadap loyalitas nasabah.

Berdasarkan uji t untuk daya tanggap thitung sebesar 4,212 dan tabel sebesar 1,966 ( $\left.\mathrm{t}_{\text {hitung }}>\mathrm{t}_{\text {tabel }}\right)$. Kemudian dari tingkat signifikan $\mathrm{t}$ sebesar 0,000 lebih kecil dari $0,05(0,000<0,05)$ maka hipotesis penelitian ini menolak Ho dan menerima Ha. Hipotesis yang menyatakan menerima Ha menunjukkan bahwa variabel daya tanggap secara partial memiliki pengaruh yang signifikan terhadap loyalitas nasabah.

Berdasarkan uji $\mathrm{t}$ untuk jaminan memiliki nilai $\mathrm{t}_{\text {hitung }}$ sebesar 3,635 dan $\mathrm{t}_{\text {tabel }}$ sebesar 1,966 ( $\left.t_{\text {hitung }}>t_{\text {tabel }}\right)$. Kemudian dari tingkat signifikan $t$ sebesar 0,000 lebih kecil dari $0,05(0,000<0,05)$ maka hipotesis penelitian ini menolak Ho dan menerima Ha. Hipotesis yang menyatakan menerima Ha menunjukkan bahwa variabel jaminan secara partial memiliki pengaruh yang signifikan terhadap loyalitas nasabah.

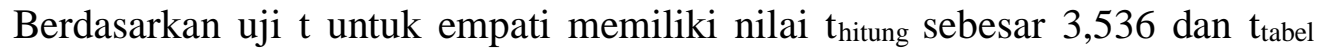
sebesar 1,966 ( $\left.t_{\text {hitung }}>t_{\text {tabel }}\right)$. Kemudian dari tingkat signifikan $t$ sebesar 0,000 lebih kecil dari $0,05(0,000<0,05)$ maka hipotesis penelitian ini menolak Ho dan menerima Ha. Hipotesis yang menyatakan menerima Ha menunjukkan bahwa variabel empati secara partial memiliki pengaruh yang signifikan terhadap loyalitas nasabah.

\section{KESIMPULAN}

Penelitian ini bertujuan untuk menguji pengaruh kualitas layanan SMS Banking terhadap loyalitas nasabah pada Bank Rakyat Indonesia kantor cabang Madiun. Berdasarkan analisis dan hasil penelitian dapat diambil beberapa kesimpulan sebagai berikut:

1. Variabel bukti fisik berpengaruh signifikan secara parsial terhadap loyalitas nasabah Bank Rakyat Indonesia kantor cabang Madiun. Hal ini menunjukan bahwa kualitas layanan dari dimensi bukti fisik mempengaruhi loyalitas nasabah Bank Rakyat Indonesia kantor cabang Madiun melalui SMS Banking BRI. Jadi dapat disimpulkan bahwa dengan adanya bukti fisik diantaranya seperti mesin ATM, kondisi ruangan yang bersih dan nyaman, fasilitas fitur layanan SMS 
Banking yang lengkap, nasabah akan semakin tertarik menggunakan layanan SMS Banking yang dampaknya akan berpengaruh terhadap peningkatan laba perusahaan.

2. Variabel kehandalan berpengaruh signifikan secara parsial terhadap loyalitas nasabah Bank Rakyat Indonesia kantor cabang Madiun. Hal ini menunjukan bahwa kualitas layanan dari dimensi kehandalan mempengaruhi loyalitas nasabah Bank Rakyat Indonesia kantor cabang Madiun melalui SMS Banking BRI. Dimensi kehandalan tersebut diantaranya adalah kecepatan bertransaksi, kemudahan dan ketepatan karyawan dalam melayani nasabah. Dengan demikian dapat disimpulkan bahwa semakin baik dimensi kehandalan yang diberikan, maka loyalitas nasabah Bank Rakyat Indonesia kantor cabang Madiun akan semakin tinggi yang dampaknya akan berpengaruh terhadap peningkatan laba perusahaan.

3. Variabel daya tanggap berpengaruh signifikan secara parsial terhadap loyalitas nasabah Bank Rakyat Indonesia kantor cabang Madiun. Hal ini menunjukan bahwa kualitas layanan dari dimensi daya tanggap mempengaruhi loyalitas nasabah Bank Rakyat Indonesia kantor cabang Madiun melalui SMS Banking BRI. Dimensi daya tanggap tersebut diantaranya adalah kesigapan, kecepatan, kesediaan dan ketelitian karyawan serta mengutamakan kepentingan terbaik bagi nasabah. Dengan demikian dapat disimpulkan bahwa semakin baik daya tanggap yang diberikan, maka loyalitas nasabah Bank Rakyat Indonesia kantor Cabang Madiun akan semakin tinggi sehingga berdampak terhadap peningkatan laba perusahaan.

4. Variabel jaminan berpengaruh signifikan secara parsial terhadap loyalitas nasabah Bank Rakyat Indonesia Kantor cabang Madiun. Hal ini menunjukan bahwa kualitas layanan dari dimensi jaminan mempengaruhi loyalitas nasabah Bank Rakyat Indonesia kantor cabang Madiun melalui SMS Banking BRI. Dimensi jaminan tersebut diantaranya adalah karyawan yang memiliki pengetahuan luas, keramahan karyawan, keamanan bertransaksi, jaminan bertransaksi dan menanamkan kepercayaan kepada nasabah. Dengan demikian dapat disimpulkan bahwa semakin baik jaminan yang diberikan oleh pihak BRI maka loyalitas nasabah Bank Rakyat Indonesia kantor cabang Madiun akan semakin tinggi sehingga berdampak terhadap peningkatan laba perusahaan.

5. Variabel Empati berpengaruh signifikan secara parsial terhadap loyalitas nasabah Bank Rakyat Indonesia kantor cabang Madiun. Hal ini menunjukan bahwa kualitas layanan dari dimensi empati mempengaruhi loyalitas nasabah Bank Rakyat Indonesia kantor cabang Madiun melalui SMS Banking BRI. Dimensi empati tersebut diantaranya adalah penyampaian informasi kepada nasabah, sikap dan perilaku yang baik dari karyawan, tegur sapa dan tutur kata karyawan yang sopan kepada nasabah. Sehingga dapat disimpulkan bahwa semakin baik empati yang diberikan, maka loyalitas nasabah Bank Rakyat Indonesia kantor Cabang Madiun akan semakin tinggi sehingga berdampak terhadap peningkatan laba perusahaan.

6. Variabel bukti fisik, kehandalan, daya tanggap, jaminan dan empati berpengaruh signifikan secara simultan terhadap loyalitas nasabah Bank Rakyat Indonesia kantor cabang Madiun. Hal ini menunjukan bahwa kualitas layanan yang terdiri dari dimensi bukti fisik, kehandalan, daya tanggap, jaminan dan empati secara komprehensif mempengaruhi loyalitas nasabah Bank Rakyat Indonesia kantor cabang Madiun melalui SMS Banking BRI. 


\section{SARAN}

Berdasarkan dari hasil penelitian bahwa kualitas layanan SMS Banking BRI yang terdiri dari bukti fisik, kehandalan, daya tanggap, jaminan dan empati terbukti berpengaruh signifikan baik secara parsial maupun secara simultan terhadap loyalitas nasabah. Dengan demikian Bank Rakyat Indonesia diharapkan terus secara konsisten melakukan dan meningkatkan kualitas layanan yang terdiri dari bukti fisik, kehandalan, daya tanggap, jaminan dan empati secara menyeluruh dengan cara menambah sarana-prasarana kelengkapan penunjang transaksi seperti mesin ATM, memberikan layanan yang cepat, akurat, tanggap, bebas dari resiko dan memberikan perhatian yang tulus kepada nasabah agar loyalitas semakin meningkat sehingga dapat memberikan kontribusi kepada Bank Rakyat Indonesia berupa peningkatan laba perusahaan.

\section{DAFTAR PUSTAKA}

Divisi Layanan PT Bank Rakyat Indonesia. 2008. Buku Prosedur Operasional SMS Banking. Tanpa Kota: PT Bank Rakyat Indonesia (Persero), Tbk.

Duwi Priyatno. 2009. SPSS Untuk Analisis Korelasi, Regresi, dan Multivariate. Yogyakarta : Gava Media.

Duwi Priyatno. 2013. Analisis Korelasi, Regresi dan Multivariate dengan SPSS. Yogyakarta: Gava Media.

Ernani Hidayati. 2010. Analisis Kualitas Pelayanan Dan Pengaruhnya Terhadap Loyalitas Pelanggan. Jurnal Menejemen (Online), Vol.2, No.2. ISSN : 2085 - 0972, (http://Journal.unja.ac.id, Diunduh 25 Maret 2014).

Gunawan Adi Saputro. 2010. Manajemen Pemasaran Analisis Untuk Perancangan Strategi Pemasaran. Yogyakarta: Unit Penerbit dan Percetakan Sekolah Tinggi Ilmu Manajemen YKPN.

H. Imam Ghozali. 2012. Aplikasi Analisis Multivariate Dengan Program IBM SPSS 20. Semarang : Badan Penerbit Universitas Diponegoro.

H. Malayu S.P Hasibuan. 2011. Dasar-Dasar Perbankan. Jakarta : PT Bumi Aksara.

Hais Dama. 2010. Pengaruh Kualitas Pelayanan Terhadap Loyalitas Nasabah Pada Bank Mandiri Cabang Gorontalo. Inovasi (Online), Vol.2, No.2. ISSN : 1693 9034,(http://Digilip.esaunggul.ac.id, Diunduh 26 Maret 2014).

Hengky Latan dan Selva Temalagi. 2013. Analisis Multivariate Teknik Dan Aplikasi Menggunakan Program IBM SPSS 20.0. Bandung : Alfabeta.

J. Supranto. 2011. Pengukuran Tingkat Kepuasan Pelanggan Untuk Meningkatkan Pangsa Pasar. Jakarta : Rineka Cipta.

Jonathan Sarwono dan Ely Suhayati. 2010. Riset Akuntansi Menggunakan SPSS. Yogyakarta: Graha Ilmu.

Juhari. 2012. Analisis Pengaruh Kualitas Layanan Terhadap Loyalitas Pelanggan Pada Hotel Centrum Pangkalpinang. Ilmiah : Jurnal Analisis Pengaruh Kualitas (Online), Vol.IV, No.3,(https://Juhari_tz.files.wordpress.com, Diunduh 26 Maret 2014).

Kasmir. 2007. Menejemen Perbankan. Jakarta: PT Raja Grafindo Persada.

Kasmir. 2010. Pemasaran Bank. Jakarta : Kencana Prenada Media Group.

Ketut Gunawan dan Sundring Pantja Djati. 2011. Kualitas Layanan Dan Loyalitas Pasien (Studi Pada Rumah Sakit Umum Swasta Di Kota Singaraja - Bali). Jurnal Manejemen Dan Kewirausahaan (Online), Vol.13, No.1, (https://id.scribd.com, Diunduh 25 Maret 2014).

Philip Kotler dan Kevin Lane Keller. 2009. Menejemen Pemasaran. Jakarta: Erlangga.

Rambat Lupiyoadi dan A. Hamdani. 2008. Manajemen Pemasaran Jasa. Jakarta: Salemba Empat. 
Siti Fatona. 2010. Kualitas Jasa Yang Mempengaruhi Loyalitas dan Relevansinya terhadap Kepuasan. Jurnal Dinamika Manajemen (Online), Vol.1, No.1, (http://Journal.unnes.ac.id, Diunduh 26 Maret 2014).

Sugiono. 2012. Metode Penelitian Kuantitatif Kualitatif dan $R \&$ D. Bandung: Alfabeta.

Wiji Nurastuti. 2011. Teknologi Perbankan. Yogyakarta : Graha Ilmu.

Winarti Setyorini. 2011. Pengaruh Kualitas Pelayanan Terhadap Loyalitas Pelanggan Pada Hotel Mahkota Di Pangkalan Bun. Jurnal Ilmu - ilmu Sosial (Online),Vol.3. No.1, (http://kopertis11.net, Diunduh 26 Maret 2014).

Yasid. 2008. Pemasaran Jasa Konsep dan Implementasi. Yogyakarta : Ekonisia.

Zulian Yamit. 2010. Manajemen Kualitas Produk \& Jasa. Yogyakarta : Ekonisia.

— 1998. Undang-Undang RI Tentang Perbankan Nomor 10 tahun 1998. Jakarta

2007. Peraturan Bank Indonesia No.9/15/PBI/2007 Tentang Penerapan Manajemen Risiko Dalam Penggunaan Teknologi Informasi Oleh Bank Umum. Jakarta. 